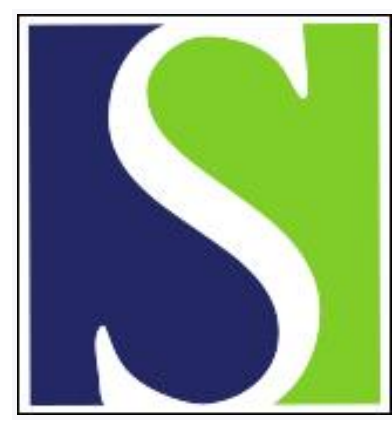

Scand J Work Environ Health 2005;31(2):160-163

https://doi.org/10.5271/sjweh.863

Issue date: Apr 2005

Occupational relevance of subclavian vein thrombosis in association with thoracic outlet syndrome

by Fiorentini C, Mattioli S, Graziosi F, Bonfiglioli R, Armstrong TJ, Violante FS

Affiliation: Unità Operativa di Medicina del Lavoro, Azienda Ospedaliera di Bologna, Policlinico S Orsola-Malpighi, Via P Palagi, 9, I-40138 Bologna, Italy. cristiana.fiorentini@unibo.it

Key terms: biomechanical assessment; biomechanics; case report; effort thrombosis; occupational disease; occupational relevance; subclavian vein thrombosis; thoracic outlet syndrome; work-related disease

This article in PubMed: www.ncbi.nlm.nih.gov/pubmed/15864910 


\title{
Occupational relevance of subclavian vein thrombosis in association with thoracic outlet syndrome
}

\author{
by Cristiana Fiorentini, MD, ${ }^{1}$ Stefano Mattioli, MD, ${ }^{1}$ Francesca Graziosi, MSc, ${ }^{2}$ Roberta Bonfiglioli, MD, ${ }^{1}$ \\ Thomas J Armstrong, PhD, ${ }^{3}$ Francesco S Violante, $M D^{2}$
}

Fiorentini C, Mattioli S, Graziosi F, Bonfiglioli R, Armstrong TJ, Violante FS. Occupational relevance of subclavian vein thrombosis in association with thoracic outlet syndrome. Scand J Work Environ Health 2005;31(2):160-163.

\begin{abstract}
Objectives Primary subclavian vein thrombosis ("effort thrombosis") is not generally recognized as a workrelated disorder, and more knowledge is required on the particular biomechanical risks. An extensive biomechanical risk analysis was performed for a possible work-related case.

Case report A hard-working 43-year-old race-course farrier received successful surgical treatment for subclavian vein thrombosis. No congenital abnormalities were apparent. At work, the farrier spent $75 \%$ of his time with his back bent (generally at $>70$ degrees) with his right shoulder flexed and abducted, a position that thereby increased the pressure on the subclavian vein. High average (and peak) stress ratings for the neck and shoulder postures are accompanied by high levels of force and considerable repetitiveness.

Conclusions Taken together, these forms of biomechanical overload suggest that the leading cause of the subclavian thrombosis suffered by this farrier could have been occupational. Case-control studies on this neglected topic are needed to investigate possible associations between subclavian vein thrombosis and specific occupational activities.
\end{abstract}

Key terms biomechanics; biomechanical assessment; case report; effort thrombosis; occupational disease; work-related disease.

Subclavian venous thrombosis occurs in about 2 of every 100000 persons a year and accounts for $\sim 1-2 \%$ of deep venous thrombi (1). It is commonly classified as primary or secondary (1). Primary subclavian thrombosis-also known as "effort thrombosis" or PagetSchroetter syndrome-occurs in the absence of recognized risk factors or diseases (central venous catheter, malignancies, hypercoagulability, effects of surgery) and is often associated with repetitive or strenuous exercise $(1,2)$. It is often associated with compressioninduced neurovascular disorders between the neck and shoulder commonly known as "thoracic outlet syndrome" $(3,4)$. Thoracic outlet syndrome can be caused by occupational (posture, force of exertion) $(4,5)$ and nonoccupational [congenital defects, including cervical ribs, long C-7 transverse processes, fibrous and ligamentous bands, and abnormal muscles $(5,6)$ and traumatic factors, including fractured clavicles and subacromial dislocations of the humeral head (7)] factors. Subclavian vein thrombosis is not generally recognized as a work-related disorder (8), and more knowledge is required on the particular biomechanical risks. We report an extensive biomechanical risk analysis of a case of subclavian vein thrombosis occurring in a hard-working race-course farrier.

\section{Case report}

In 1997, a 43-year-old, previously healthy, race-course farrier started to experience bilateral nocturnal paresthesias of the hands and upper limbs; the symptoms were more severe on the right side. In 1998, he was forced to reduce his workload due to the easy fatigability of the right upper extremity and to the increasing symptoms of tingling and weakness, exacerbated by his usual activities. Mindful that his father (who was also a farrier)

1 Occupational Medicine Unit, Sant'Orsola-Malpighi Hospital, Bologna, Italy.

2 Alma Mater Studiorum-University of Bologna, Occupational Medicine Unit, Sant'Orsola-3, Malpighi Hospital, Bologna, Italy.

3 Center for Ergonomics University of Michigan, Ann Arbor, Michigan, USA.

Correspondence to: Dr Cristiana Fiorentini; Unità Operativa di Medicina del Lavoro, Azienda Ospedaliera di Bologna, Policlinico S Orsola-Malpighi, Via P Palagi, 9, I-40138 Bologna, Italy. [E-mail: cristiana.fiorentini@ unibo.it] 
had experienced a similar symptomatology a few years before suffering cerebral ictus, in 1999 the farrier finally consulted his family doctor, complaining of persistent pain and numbness, fatigability, and frequent cramps extending bilaterally throughout the upper limbs (especially on the right side). His doctor requested color flow Doppler ultrasonography. The procedure revealed bilateral functional stenosis of the axillary-subclavian vein, which was more severe on the right side. A subsequent angiography-assisted computer tomography (CT) scan confirmed the presence of right subclavian (and superior cava) venous thrombosis.

The farrier was urgently admitted to the hospital, where he was immediately treated with heparin anticoagulation and urokinase thrombolytic therapy. Routine coagulation tests showed a normal profile (quick time, 114\%; partial prothrombin time, 31 seconds; fibrinogen, $222 \mathrm{mg} / \mathrm{dl}$; antithrombin III, 101\%; platelet count, 163 $\left.\times 10^{3} / \mu \mathrm{l}\right)$. On day 3 of his hospitalization, contrast venography, performed to monitor thrombolytic therapy, showed a persistence of bilateral (especially rightside) functional stenosis of the axillo-subclavian vein crossing the first rib, with signs of thrombosis extending to the superior cava. Catheter-directed local urokinase infusion led to complete recanalization of the superior vena cava and the axillary subclavian vein bilaterally after 24 hours. Coagulation tests continued to show a therapy-compatible profile (eg, at discharge on day 6: quick time, $100 \%$; partial prothrombin time, 40 seconds; fibrinogen, $182 \mathrm{mg} / \mathrm{dl}$; antithrombin III, 91\%). In the following months, planned bilateral surgical treatment was performed (2 operations), with partial resection of the first rib and total resection of the anterior scalene muscle to relieve the thoracic compression. No evidence of fibrous or ligamentous bands or abnormal muscles was reported by the surgeons. Subsequent routine Doppler ultrasound examinations were normal (both at rest and during abduction) until 2001, when bilateral occlusion of the subclavian vein was observed during abduction (total occlusion at 80 degrees on the right side; partial occlusion at 110 degrees on the left side); a repeat examination in 2002 showed similar findings (total occlusion at 110 degrees on both sides). In addition, in 2001, an electroneuromyographic diagnosis was made of bilateral carpal tunnel syndrome (more accentuated on the right side) - a possible explanation or contributing factor for the paresthesias.

In 2003, the farrier was referred to our institution for assessment of a possible occupational origin of the subclavian vein thrombosis for insurance reasons. Other secondary causes of thrombosis were taken into consideration. The farrier reported that he had never smoked, experienced thoracic trauma or fracture, or undergone previous surgery. He had not been doing any kind of sport. No additional rib or other congenital anomalies were present in the clinical reports (a further CT scan did not seem warranted on ethical grounds, especially when no anomalies had been evident in the extensive bilateral surgical treatment). Familial anamnesis revealed that the father-another hard-working farrierhad also suffered from nocturnal paresthesias and easy fatigability of the upper arm; he had a cerebral ictus when aged 62 years and had died at 72 years of age from acute myocardial infarction.

To investigate how the farrier's job task might have contributed to the condition, we performed a biomechanical evaluation of his work and associated physical stresses.

\section{Assessment of potential biomechanical risk factors}

The job evaluation included a worker interview to determine the tasks and their frequency and duration; observations and video-recording were performed of each task so that any physical stresses could be identified (9).

For 34 years, the farrier had worked 6 days a weekfor at least 8 hours/day during winter and 12 hours/day in summer. [Since 1998, he had been working about 45 hours/day in winter and 7-8 hours/day in summer.] Shoeing a horse takes about 1-2 hours, depending on the difficulty of the animal. A typical cycle of shoeing tasks (duration, 70 minutes) with a "quiet" horse was video-taped (table 1). The percentage times (with respect to cycle time), tools, postures, and force required were estimated from the video, which was systematically reviewed to verify the estimates. Four independent observers (CF, FG, SM, and RB) estimated peak and average stress ratings (9) for the neck and shoulder postures in association with each task in terms of flexion, extension, and abduction on a scale from 0 (neutral) to 10 (most extreme position possible); the reported ratings are the result of averages (for interobserver discrepancies $\leq 1$ ) or consensus after a detailed team discussion (discrepancies $>1$ ).

The main results of the biomechanical assessment are shown in table 1. (With the exception of the hammering, the posture was symmetrical, and the posture values reported for the right side were similar on the left side; data not shown.) The farrier spent $75 \%$ of his time with his back bent (generally at $>70$ degrees) and $90 \%$ of the time with his right shoulder flexed and abducted (range 50-80 degrees) while performing repetitive, forceful tasks. The latter included hammering or power-gripping with internal or external rotation of the abducted or flexed shoulder (overall, about $60 \%$ of the time is spent hammering). High to medium-high levels of force are required for $76 \%$ of the time for gripping and also (with recruitment of all groups of agonist and antagonist shoulder muscles) for hammering, holding, pushing, pulling, and filing. The job required repetitive movements: the farrier executed about 1 exertion a sec- 
Table 1. Summary of the postural and biomechanical assessment of farrier work. $\left({ }^{\circ}=\right.$ degrees $)$

\begin{tabular}{|c|c|c|c|c|c|c|c|c|c|c|c|c|}
\hline \multirow[t]{2}{*}{ Task } & \multirow[t]{2}{*}{$\begin{array}{l}\text { Per- } \\
\text { centage } \\
\text { of cycles } \\
\text { of } 70 \mathrm{mi}- \\
\text { nutes }\end{array}$} & \multirow[t]{2}{*}{$\begin{array}{l}\text { Equip- } \\
\text { ment } \\
\text { used }\end{array}$} & \multirow[t]{2}{*}{$\begin{array}{l}\text { Whole-body } \\
\text { posture }\end{array}$} & \multicolumn{2}{|c|}{$\begin{array}{l}\text { Ratings } \\
\text { of neck } \\
\text { posture } \\
\text { stress }\end{array}$} & \multirow[t]{2}{*}{$\begin{array}{l}\text { Right-hand } \\
\text { posture }\end{array}$} & \multirow[t]{2}{*}{$\begin{array}{l}\text { Right } \\
\text { shoulder } \\
\text { posture } \\
\text { (range) }\end{array}$} & \multicolumn{2}{|c|}{$\begin{array}{l}\text { Ratings } \\
\text { of right } \\
\text { shoulder } \\
\text { posture } \\
\text { stress }\end{array}$} & \multirow[t]{2}{*}{$\begin{array}{l}\text { Force } \\
\text { requir- } \\
\text { ed } \\
\text { (over- } \\
\text { all) }\end{array}$} & \multirow[t]{2}{*}{$\begin{array}{l}\text { Frequen- } \\
\text { cy (ex- } \\
\text { ertion per } \\
\text { second) }\end{array}$} & \multirow[t]{2}{*}{ Images } \\
\hline & & & & Peak & Mean & & & Peak I & Mean & & & \\
\hline $\begin{array}{l}\text { Removal of } \\
\text { the old horse- } \\
\text { shoe, and } \\
\text { brushing off } \\
\text { the hoof }\end{array}$ & 3 & Tongs & $\begin{array}{l}\text { Back constant- } \\
\text { ly bent forward } \\
\left(70-90^{\circ}\right) \text {, knee } \\
\text { flexed }\end{array}$ & 8 & 6.5 & $\begin{array}{l}\text { Power grip; fle- } \\
\text { xion or exten- } \\
\text { sion radial or } \\
\text { ulnar deviation } \\
\text { of the wrist }\end{array}$ & $\begin{array}{l}\text { Abduction } \\
\left(10-30^{\circ}\right) \text {, } \\
\text { flexion } \\
\left(40-70^{\circ}\right)\end{array}$ & 5 & 4 & High & 0.4 & \\
\hline $\begin{array}{l}\text { Removal of } \\
\text { hoof layers } \\
\text { (surface and } \\
\text { deep) }\end{array}$ & 10 & $\begin{array}{l}\text { Hammer, } \\
\text { hoof } \\
\text { knife, } \\
\text { pincers }\end{array}$ & $\begin{array}{l}\text { Back constant- } \\
\text { ly bent forward } \\
\left(60-80^{\circ}\right) \text {, knee } \\
\text { flexed }\end{array}$ & 7.5 & 6.5 & Power grip & $\begin{array}{l}\text { Internal or } \\
\text { external rota- } \\
\text { tion abduc- } \\
\text { tion }\left(40-90^{\circ}\right) \text {, } \\
\text { flexion } \\
\left(30-80^{\circ}\right)\end{array}$ & 7 & 5 & High & 1.3 & \\
\hline $\begin{array}{l}\text { Filing of the } \\
\text { hoof }\end{array}$ & 7 & File & $\begin{array}{l}\text { Back constantly } \\
\text { bent forward } \\
\left(80-90^{\circ}\right) \text {, knee } \\
\text { flexed }\end{array}$ & 8.5 & 7.5 & $\begin{array}{l}\text { Power grip; fle- } \\
\text { xion of the wrist }\end{array}$ & $\begin{array}{l}\text { Abduction } \\
\left(60-90^{\circ}\right) \text {, ex- } \\
\text { tension or } \\
\text { flexion } \\
\left(-30-50^{\circ}\right)\end{array}$ & 7 & 5 & $\begin{array}{l}\text { Me- } \\
\text { dium }\end{array}$ & 1.1 & \\
\hline $\begin{array}{l}\text { Heating and } \\
\text { striking of } \\
\text { the iron }\end{array}$ & 21 & $\begin{array}{l}\text { Tongs, } \\
\text { hammer, } \\
\text { anvil }\end{array}$ & Standing & 4 & 3 & $\begin{array}{l}\text { Power grip; } \\
\text { ulnar deviation }\end{array}$ & $\begin{array}{l}\text { Internal or } \\
\text { external rota- } \\
\text { tion abduc- } \\
\text { tion }\left(20-40^{\circ}\right) \text {, } \\
\text { flexion } \\
\left(30-100^{\circ}\right)\end{array}$ & 7.5 & 5 & High & 1.1 & \\
\hline $\begin{array}{l}\text { Preliminary } \\
\text { placement of } \\
\text { the horseshoe }\end{array}$ & 14 & Tongues & $\begin{array}{l}\text { Back constantly } \\
\text { bent forward } \\
\left(80-100^{\circ}\right) \text {, knee } \\
\text { flexed }\end{array}$ & 9 & 7 & Power grip & $\begin{array}{l}\text { Abduction } \\
\left(30-60^{\circ}\right), \\
\text { flexion } \\
\left(60-80^{\circ}\right)\end{array}$ & 6 & 5 & Low & 0.04 & \\
\hline $\begin{array}{l}\text { Fitting of the } \\
\text { horseshoe }\end{array}$ & 14 & $\begin{array}{l}\text { Nails, } \\
\text { hammer, } \\
\text { retractor }\end{array}$ & $\begin{array}{l}\text { Back bent forward } \\
\left(80-100^{\circ}\right) \text {, fixed } \\
\text { knee flexed }\end{array}$ & d 9 & 7.5 & $\begin{array}{l}\text { Power grip; } \\
\text { radial or ulnar } \\
\text { deviation, maxi- } \\
\text { mum extension } \\
\text { of the wrist }\end{array}$ & $\begin{array}{l}\text { Internal or } \\
\text { external rota- } \\
\text { tion abduc- } \\
\text { tion } \\
\left(40-100^{\circ}\right) \\
\text { flexion } \\
\left(30-90^{\circ}\right)\end{array}$ & 7 & 4 & $\begin{array}{l}\text { Me- } \\
\text { dium- } \\
\text { high }\end{array}$ & 1.1 & \\
\hline $\begin{array}{l}\text { Cutting and } \\
\text { riveting of } \\
\text { nails }\end{array}$ & 14 & $\begin{array}{l}\text { Pincers, } \\
\text { hammer }\end{array}$ & $\begin{array}{l}\text { Back bent for- } \\
\text { ward }\left(80-100^{\circ}\right) \text {, } \\
\text { fixed knee flexed }\end{array}$ & 9.5 & 8 & Power grip & $\begin{array}{l}\text { Internal or ex- } \\
\text { ternal rotation } \\
\text { abduction } \\
\left(50-100^{\circ}\right) \text {, fle- } \\
\text { xion }\left(10-90^{\circ}\right)\end{array}$ & $\begin{array}{r}7.5 \\
-\end{array}$ & 6.5 & $\begin{array}{l}\text { Me- } \\
\text { dium- } \\
\text { high }\end{array}$ & 1.4 & \\
\hline $\begin{array}{l}\text { Finishing of the } \\
\text { hoof and } \\
\text { shoe }\end{array}$ & 14 & File & $\begin{array}{l}\text { Back bent for- } \\
\text { ward }\left(80-100^{\circ}\right) \text {, } \\
\text { fixed knee flexed }\end{array}$ & 9.5 & 7.5 & $\begin{array}{l}\text { Power grip; } \\
\text { flexion of the } \\
\text { wrist }\end{array}$ & $\begin{array}{l}\text { Abduction } \\
\left(60-90^{\circ}\right) \\
\text { flexion } \\
\left(40-90^{\circ}\right)\end{array}$ & 7 & 6.5 & $\begin{array}{l}\text { Me- } \\
\text { dium- } \\
\text { high }\end{array}$ & 2 & \\
\hline Recovery & 3 & - & - & - & - & - & - & - & - & & & \\
\hline
\end{tabular}

ond; he worked for about $90 \%$ of his workshift (considering recovery time and coffee and lunch breaks).

\section{Discussion}

Subclavian vein thrombosis ("effort thrombosis") is not a recognized work-related disorder in the United States,
Europe, or elsewhere. However, overhead tasks or sporting activities requiring acute or long-term strain on the shoulder or hyperabduction and external rotation of the arm are often implicated in the pathophysiology of effort thrombosis. Such postures occur during ceiling painting, wood chopping, typesetting, conducting, electrical work, automobile and airplane repair, construction, 
shelving jobs, porterage, hod-carrying, hammering, swimming, wrestling, volleyball or handball, tennis or squash, baseball, and bodybuilding $(2,4,8,10)$. In an uncontrolled retrospective analysis of a series of 27 patients with primary subclavian venous thrombosis, Zell et al (8) reported that 24 had exerted unusual physical strain for several days or weeks and apparently fulfilled the criteria for occupational disease. However, hard evidence is still needed to support the claim that primary subclavian venous thrombosis is an occupational disease.

The tasks performed by our patient included several major biomechanical risk factors. The farrier spent $75 \%$ of his time with his back bent (generally at $>70$ degrees) holding up the horse's hoof and using tools, with his shoulder flexed and abducted. This posture requires contraction of the muscles in the neck and shoulder and can increase pressure on and trauma to the subclavian vein. The awkward head-forward postures involve thoracic flexion, flexion and abduction, internal and external rotation of the shoulders, and increased cervical lordosis (affecting the scalene muscles). High average (and peak) stress ratings for the neck and shoulder postures are accompanied by high levels of force and considerable repetitiveness. Taken together, these forms of biomechanical overload suggest that the leading cause of the subclavian thrombosis suffered by this farrier could have been occupational. Even though a family predisposition could be present, biomechanical factors may also have at least partially accounted for the clinical history of the patient's father, who was obliged to follow a similarly intensive race-course work schedule. Furthermore, the picture of a right-sided subclavian thrombosis in association with bilateral thoracic outlet syndrome (which was more severe on the right side) reflects the generally symmetrical postures accompanied by rather greater strength values on the right side.

Pathophysiologically, effort thrombosis can be caused by microtraumas of the venous intima and by venous stasis due to repeated stretching or compression of the vein. Venous compression can occur in the triangle delimited by the anterior scalene muscle, clavicle and first rib, and in the subcoracoid space delimited by the coracoid process, pectoralis minor muscle, and ribcage. Shoulder abductions, such as those performed by our patient, stretch the neurovascular bundle under the insertion of the pectoralis muscle to the coracoid process and humerus head, much like a belt stretched around a pulley. We hypothesize that, when the shoulder is flexed and extreme internal and external rotations are repeated, the angle between the coracobrachialis and pectoralis muscles becomes sharper (especially if the muscles are hypertrophic) and thus creates mechanical stress on the vein running between them. This scenario could explain the resumption of symptoms in our pa- tient 1 year after the first partial rib resection and total resection of the anterior scalene muscle had been performed to relieve the thoracic compression (it should be emphasized that this procedure occurred in the absence of congenital anomalies and secondary causes of thrombosis).

In conclusion, our assessment of potential biomechanical risk factors for a hard-working race-course farrier with a detailed clinical history suggests that primary subclavian venous thrombosis could indeed be workrelated. Case-control studies on this neglected topic are needed to investigate possible associations between subclavian vein thrombosis and specific occupational activities. Our biomechanical assessment raises the possibility that thoracic flexion and cervical hyperextension may have an additional influence on abduction-induced functional subclavian vein stenosis. Specific functional tests are needed before subclavian vein thrombosis can be accepted as an occupational disorder.

\section{Acknowledgments}

We are grateful to Robin MT Cooke for his writing assistance and to Tatiana Franco for help in translating German references.

\section{References}

1. Meissner MH. Axillary-subclavian venous thrombosis. Rev Cardiovasc Med 2002;3 Suppl 2:S76-83.

2. Zell L, Kindermann W, Marschall F, Scheffler P, Gross J, Buchter A. Paget-Schroetter syndrome in Sports activities: case study and literature review. Angiology 2001;52:337-42.

3. Treat SD, Smith PA, Wen DY, Kinderknecht JJ. Deep vein thrombosis of the subclavian vein in a college volleyball player. Am J Sports Med 2004;32:529-32.

4. Pratikto TH, Zwetschke V, Goyen M, Kroger K. Recurrent exercise induced subclavian vein thrombosis in a conductor. Vasa 2002;31:209-11.

5. Novak CB, Mackinnon SE. Thoracic outlet syndrome. Orthop Clin North Am 1996;27:747-62.

6. Beyer JA. The hyperabduction syndrome, with special reference to its relationship to Raynaud's syndrome. Circulation 1951;4:161-72.

7. Riddell DH, Smith BM. Thoracic and vascular aspects of thoracic outlet syndrome: 1986 update. Clin Orthop 1986;207:31-6.

8. Zell L, Scheffler P, Heger M, Steuckardt-Götz A, Buchter A. The Paget-Schroetter syndrome: work accident and occupational disease. Ann Acad Med Singapore 2001; 30: 481-4.

9. Armstrong TJ. Analysis and design of jobs for control of work related musculoskeletal disorders (WMSDs). In: Violante FS, Armstrong TJ, Kilbom Å, ed. Occupational ergonomics: work related musculoskeletal disorders of the upper limb and back. London: Taylor \& Francis; 2000. p 51-81.

10. Marsh K. Subclavian vein thrombosis due to external compression. Lancet 1980 4;2:750.

Received for publication: 2 July 2004 